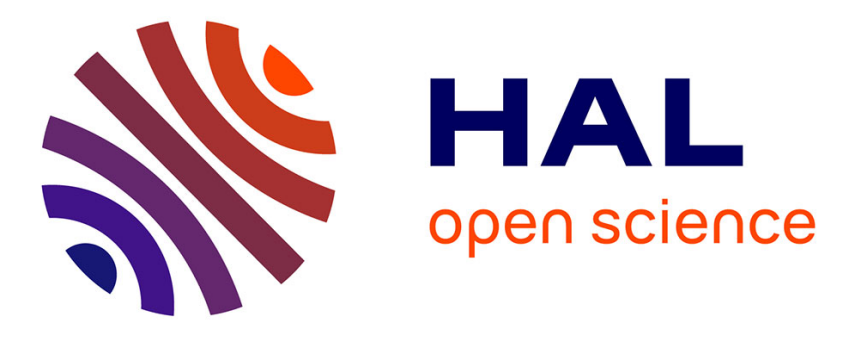

\title{
Protective effect of monosialoganglioside GM1 against chemically induced apoptosis through targeting of mitochondrial function and iron transport.
}

Morgane Gorria, Laurence Huc, Odile Sergent, Amélie Rébillard, François

Gaboriau, Marie-Thérèse Dimanche-Boitrel, Dominique Lagadic-Gossmann

\section{To cite this version:}

Morgane Gorria, Laurence Huc, Odile Sergent, Amélie Rébillard, François Gaboriau, et al.. Protective effect of monosialoganglioside GM1 against chemically induced apoptosis through targeting of mitochondrial function and iron transport.. Biochemical Pharmacology, 2006, 72 (10), pp.1343-53. 10.1016/j.bcp.2006.07.014 . hal-00699820

\section{HAL Id: hal-00699820 https://hal.science/hal-00699820}

Submitted on 30 May 2020

HAL is a multi-disciplinary open access archive for the deposit and dissemination of scientific research documents, whether they are published or not. The documents may come from teaching and research institutions in France or abroad, or from public or private research centers.
L'archive ouverte pluridisciplinaire HAL, est destinée au dépôt et à la diffusion de documents scientifiques de niveau recherche, publiés ou non, émanant des établissements d'enseignement et de recherche français ou étrangers, des laboratoires publics ou privés. 


\title{
Protective effect of monosialoganglioside GM1 against chemically induced apoptosis through targeting of mitochondrial function and iron transport
}

\author{
Morgane Gorria ${ }^{a}$, Laurence Huc ${ }^{a}$, Odile Sergent ${ }^{b}$, Amélie Rebillard ${ }^{a}$, \\ François Gaboriau ${ }^{c}$, Marie-Thérèse Dimanche-Boitrel ${ }^{a}$, \\ Dominique Lagadic-Gossmann ${ }^{a, *}$ \\ a INSERM U620, Faculté de Pharmacie, Université Rennes 1, IFR140, 2 av Pr. Léon Bernard, 35043 Rennes Cedex, France \\ ${ }^{\mathrm{b}}$ UPRES EA 3891, Université Rennes 1, 2 av Pr. Léon Bernard, 35043 Rennes Cedex, France \\ ${ }^{\mathrm{c}}$ INSERM U522, IFR 140, Hôpital Pontchaillou, Avenue de la Bataille Flandre/Dunkerque, Rennes, France
}

\section{A R T I C L E I N F O}

Article history:

Received 11 May 2006

Accepted 18 July 2006

\section{Keywords:}

Benzo[a]pyrene

Apoptosis

GM1

Intracellular $\mathrm{pH}$

Iron

Reactive oxygen species

Lipid peroxidation

Mitochondria

Abbreviations:

$\mathrm{B}[\mathrm{a}] \mathrm{P}$, benzo[a]pyrene

CYP1, cytochrome P450 1

DMSO, dimethyl sulfoxide

GM1, monosialoganglioside GM1

$\mathrm{NHE1}, \mathrm{Na}^{+} / \mathrm{H}^{+}$exchanger 1

$\mathrm{pH}_{\mathrm{i}}$, intracellular $\mathrm{pH}$

ROS, reactive oxygen species

\begin{abstract}
A B S T R A C T
Exogenous treatment with monosialoganglioside GM1 has been described to afford protection against different apoptotic insults. However, the underlying mechanisms remain to be determined. In this study, we focused on the effect of GM1 on the apoptotic cascade induced by benzo[a]pyrene $(\mathrm{B}[\mathrm{a}] \mathrm{P})$ in rat hepatic $\mathrm{F} 258$ epithelial cells. We first demonstrated that a cotreatment with GM1 $(80 \mu \mathrm{M})$ reduced $\mathrm{B}[\mathrm{a}] \mathrm{P}(50 \mathrm{nM})$-induced apoptosis as evidenced by a decrease of both cell population exhibiting nuclear fragmentation and caspase 3 cleavage and activity. We next showed that the 553 phosphorylation and nuclear translocation as well as the intracellular alkalinization related to $\mathrm{Na}^{+} / \mathrm{H}^{+}$exchanger 1 (NHE1) activation, two early events of the apoptosis induced by B[a]P, were not inhibited by GM1. In contrast, the late mitochondria-dependent acidification elicited by $\mathrm{B}[\mathrm{a}] \mathrm{P}$ was inhibited by GM1 co-treatment, and an inhibition of the oxidative stress was also observed. Because GM1 has been shown to reduce the low-molecular weight iron content related to ethanol-induced oxidative stress, we finally investigated the involvement of iron under our conditions. Using the two iron chelators deferiprone and desferrioxamine, we clearly showed that iron played an important role in $\mathrm{B}[\mathrm{a}] \mathrm{P}$-induced apoptosis in $\mathrm{F} 258$ cells, and that $\mathrm{B}[\mathrm{a}] \mathrm{P}$-treatment resulted in a significant GM1-sensitive increase in ${ }^{55} \mathrm{Fe}$ uptake. In conclusion, our results indicate that exogenous GM1 partly prevents B[a]P-induced apoptosis by interfering with mitochondriarelated intracellular acidification and iron transport.
\end{abstract}

(C) 2006 Elsevier Inc. All rights reserved.

\footnotetext{
* Corresponding author. Tel.: +33 223234837; fax: +33 223234794.

E-mail address: dominique.lagadic@rennes.inserm.fr (D. Lagadic-Gossmann). 0006-2952/\$ - see front matter (C) 2006 Elsevier Inc. All rights reserved.
} doi:10.1016/j.bcp.2006.07.014 


\section{Introduction}

Natural gangliosides have recently been described to be protective against various apoptotic signals. Monosialoganglioside (GM1) has thus been shown to prevent apoptosis induced by several stimuli, such as the protein kinase $C$ inhibitor staurosporine and C2-ceramide [1], serum/growth factor withdrawal [2], or $\mathrm{H}_{2} \mathrm{O}_{2}$-induced oxidative stress [3]. Owing to the importance of gangliosides in the development and function of the nervous system, most of the studies performed so far have focused on the protective effects of gangliosides on neuronal injuries and/or the potential attenuation of neuronal degeneration $[2,4]$. However, a few works also report on protective effects of GM1 towards injuries elicited in other cell types, such as cardiac fibroblasts [1] or hepatocytes [5,6]. The semi-synthetic GM1 ganglioside LIGA $_{20}$ has also been shown to be protective against apoptosis [3] or different injuries, such as cerebral ischemia [7]. These observations have led several groups to test the use of GM1 or its derivative LIGA $_{20}$ in clinical assays [8].

If there is an agreement on the protective effects of gangliosides on cellular damages, the action mechanisms underlying these effects and the models in which gangliosides are protective still need to be precisely evaluated. Among the possible mechanisms involved, we have recently demonstrated that GM1 was capable of inhibiting the oxidative stress induced by ethanol in rat hepatocytes in primary culture, via an effect on the pool of low molecular weight iron [6]. Whether such a mechanism can explain the protection afforded under some other conditions remains however to be tested.

Polycyclic aromatic hydrocarbons (PAHs) such as benzo[a]pyrene $(\mathrm{B}[\mathrm{a}] \mathrm{P})$ constitute a major class of widely distributed and persistent environmental contaminants, notably found in cigarette smoke and smoked food. Because of their high lipophilicity, PAHs easily enter the cell, where they can be metabolized by xenobiotic metabolizing enzymes, particularly the cytochomes P450 1 (CYP1). Depending on PAH, metabolism then leads to the production of reactive electrophilic metabolites and reactive oxygen species (ROS) that form DNA adducts and induce oxidative DNA damage, thereby causing mutations and cancer initiation [9]. Besides their welldescribed carcinogenic effects, PAHs are also known to induce acute toxicity, especially through apoptosis induction in different cell types, e.g. hepatic cells $[10,11]$, ovarian germ cells [12] or thymocytes [13].

To our knowledge, no study has yet focused on the possible effects of exogenous gangliosides on the apoptosis induced upon DNA damage, that is, following activation of the tumor suppressor $\mathrm{p} 53$. The present work was thus performed in order to test the potential effects of GM1 on the apoptosis induced by the prototype DNA damaging agent $\mathrm{B}[\mathrm{a}] \mathrm{P}$ in $\mathrm{F} 258$ hepatic epithelial cell line. This model of slow $\mathrm{B}[\mathrm{a}] \mathrm{P}$-induced apoptosis allows investigating the effects of GM1 on different steps of the apoptotic pathways induced by a low concentration of this carcinogen $(50 \mathrm{nM})$. Indeed, we have previously shown that two pathways were involved in the development of apoptosis in F258 cells: the p53 pathway due to DNA damage and a permissive pathway resulting from $\mathrm{Na}^{+} / \mathrm{H}^{+}$exchanger 1 (NHE1) activation triggered by the early ROS production resulting from PAH-metabolism via CYP1 activity [10]. These two pathways have been further shown to target mitochondria in these cells, leading to late ROS production, secondary intracellular acidification and caspase activation. Therefore, this model of apoptosis appears to be appropriate for testing the effects of GM1 on different intracellular apoptotic events.

The present study indicates that a co-treatment with GM1 reduces $\mathrm{B}[\mathrm{a}] \mathrm{P}$-induced apoptosis, through an effect on mitochondria-dependent acidification and ROS production as well as interference with uptake of low molecular weight iron.

\section{Methods}

\subsection{Chemicals}

$\mathrm{B}[a] \mathrm{P}, \alpha$-naphthoflavone $(\alpha-\mathrm{NF})$ and desferrioxamine were purchased from Sigma-Aldrich (Saint Quentin Fallavier, France). Monosialoganglioside GM1 was purchased from Alexis (Coger, Paris, France), and deferiprone (1,2-dimethyl-3-hydroxy-4pyridone) from Acros (Acros Organics, Noisy Le Grand, France).

\subsection{Cell culture and treatment}

F258 cells were grown in Williams' E Medium (Gibco Invitrogen Corporation, Paisley, Scotland, UK) supplemented with $10 \%$ FCS, $5 \mathrm{U} / \mathrm{mL}$ of penicillin, $0.5 \mathrm{mg} / \mathrm{mL}$ streptomycin and $2 \mathrm{mM} \mathrm{L-}$ glutamine in a humidified atmosphere, in $5 \% \mathrm{CO}_{2}$ at $37{ }^{\circ} \mathrm{C}$. Cells growing in exponential phase were treated with $50 \mathrm{nM}$ $\mathrm{B}[\mathrm{a}] \mathrm{P}$ and/or the different test compounds (applied to cells $2 \mathrm{~h}$ prior to $\mathrm{B}[\mathrm{a}] \mathrm{P}$ exposure) for various treatment times.

\subsection{Visualization of chromatin fragmentation}

After treatment, both adherent and floating F258 cells were collected, centrifuged and incubated with the nuclear dye Hoechst 33342 (0.5 $\mu \mathrm{g} / \mathrm{mL}$; Molecular Probes, Leiden, Holland) in phosphate-buffered saline (PBS), at room temperature for $15 \mathrm{~min}$. The percentage of apoptotic cells was determined by UV fluorescence microscopy (Olympus BX60), counting nuclei with condensed or fragmented chromatin (i.e. morphology corresponding to late apoptotic cells) beyond a total of a minimum of 200 nuclei counted (normal and apoptotic). At least three independent experiments were performed per condition tested.

\subsection{Measurement of caspase-3 activity}

Caspase activity assay has been previously described [14]. Briefly, both adherent and floating F258 cells were lysed in the caspase activity buffer. A $40 \mu \mathrm{g}$ of crude cell lysate proteins were incubated with $80 \mu \mathrm{M}$ DEVD-AMC for $2 \mathrm{~h}$ at $37^{\circ} \mathrm{C}$. Caspasemediated cleavage of DEVD-AMC was measured by spectrofluorimetry (Spectramax Gemini, Molecular Devices, Sunnyvale, CA, USA) at the excitation/emission wavelength pair of $380 / 440 \mathrm{~nm}$. Three independent experiments, performed in triplicate, were carried out for each experimental condition.

\subsection{Western blot analysis of caspase-3 cleavage}

After treatment, both floating and adherent cells were harvested, centrifuged, washed with PBS and lysed for 
20 min on ice in RIPA buffer (50 mM Tris-HCl, pH 8, $150 \mathrm{mM}$ $\mathrm{NaCl}, 5 \mathrm{mM}$ EDTA, $50 \mathrm{mM} \mathrm{NaF}, 1 \%$ Triton $\mathrm{X}-100,0.5 \%$ sodium deoxycholate and $0.1 \%$ SDS) supplemented with $1 \mathrm{mM}$ phenylmethylsulfonyl fluoride (PMSF), $5 \mu \mathrm{g} / \mathrm{mL}$ leupeptin, $0.5 \mu \mathrm{g} / \mathrm{mL}$ aprotinin, $0.5 \mathrm{mM}$ dithiothreitol (DTT) and $1 \mathrm{mM}$ $\mathrm{Na}_{3} \mathrm{VO}_{4}$. Then, DNA and cell debris were removed by centrifugation at $13,000 \mathrm{rpm}$ for $15 \mathrm{~min}$ at $4{ }^{\circ} \mathrm{C}$. The resulting supernatants were collected and frozen at $-80{ }^{\circ} \mathrm{C}$. A $40 \mu \mathrm{g}$ of proteins from each sample were analyzed by $12.5 \%$ SDSpolyacrylamide gel electrophoresis and electroblotted overnight onto nitrocellulose membranes (Amersham Biosciences Europe, Orsay, France). Following a $2 \mathrm{~h}$-blocking period with Tris-buffered saline (TBS) containing 4\% BSA and 0.1\% Tween 20 , at room temperature, membranes were incubated for $2 \mathrm{~h}$ with rabbit anti-caspase 3 antibody (sc-7148, Santa Cruz Biotechnology, Tebu-bio SA, Le Perray en Yvelynes, France). After washing with TBS-Tween $0.1 \%$, blots were finally incubated with anti-rabbit horseradish peroxidase-conjugated secondary antibody for $1 \mathrm{~h}$ at room temperature and proteins were visualized by chemiluminescence. Equal loading was checked by mouse anti-HSC 70 (sc-7298, Santa Cruz Biotechnology) immunoblotting.

\subsection{Water-soluble $\mathrm{B}[\mathrm{a}] \mathrm{P}$ metabolite analysis}

Water-soluble $\mathrm{B}[a] \mathrm{P}$ metabolite production was analyzed using the chloroform/methanol extraction technique [15].

F258 cells were pretreated for $24 \mathrm{~h}$ with $10 \mathrm{nM}$ TCDD (tetrachlorodibenzo-p-dioxin, Cambridge Isotopes Laboratories, Cambridge, MA, USA), in order to induce CYP1 family members. Cells were then treated with $50 \mathrm{nM}{ }^{3} \mathrm{H}-\mathrm{B}[\mathrm{a}] \mathrm{P}(50 \mathrm{Ci} /$ $\mathrm{mmol}$, Isobio, Fleurus, Belgium) in the absence or presence of either $\alpha$-NF $(10 \mu \mathrm{M})$ or GM1 $(80 \mu \mathrm{M})$. After washing with PBS, cells were lysed in $400 \mu \mathrm{L}$ of water and B[a]P metabolites of cell lysates were separated using $9 \mathrm{~mL}$ of chloroform/methanol (v/ $\mathrm{v}, 2 / 1$ ). The radioactivity of the water-soluble phase (containing water-soluble $\mathrm{B}[\mathrm{a}] \mathrm{P}$ metabolites) was analyzed by scintillation counting (Beckman Coulter). Results, expressed as percentage of vehicle (DMSO), untreated counterparts, are given as means of three independent experiments.

\subsection{Immunofluorescence labeling of phosphorylated-p53}

F258 cells were seeded on glass coverslips and treated. After washing in PBS, adherent cells were fixed with $4 \%$ paraformaldehyde in PBS for $30 \mathrm{~min}$ at $4{ }^{\circ} \mathrm{C}$ and then washed three times with PBS. Cells were next incubated for $1 \mathrm{~h}$ at room temperature with a blocking-permeabilizing solution $(0.2 \%$ saponin-0.2\% BSA in PBS), and then incubated for $2 \mathrm{~h}$ at room temperature with primary rabbit polyclonal antibody p-p53 $\left(\mathrm{Ser}^{15}\right)$-R (sc-11764-R; Santa Cruz Biotechnology). After washing, cells were stained with TRITC-conjugated anti-rabbit IgG for $1 \mathrm{~h}$ at room temperature. Thereafter, cells were co-stained by applying a 15 min-incubation in a blocking solution containing $1 \mu \mathrm{g} / \mathrm{mL}$ DAPI, a fluorescent dye specific for DNA. After washing, coverslips were finally mounted with PBSglycerol-Dabco. Fluorescent-labeled cells were captured with a DMRXA Leica microscope and a COHU high performance CCD camera, using Metavue software. Data are representative of three independent experiments.

\subsection{Reactive oxygen species (ROS) production}

Kinetic studies previously performed in the F258 cell model have shown that $24 \mathrm{~h}$ of $\mathrm{B}[\mathrm{a}] \mathrm{P}(50 \mathrm{nM})$-treatment resulted in an $\mathrm{H}_{2} \mathrm{O}_{2}$ production (analyzed by $\mathrm{H}_{2}$-DCFDA), in the absence of any $\mathrm{O}_{2}{ }^{\bullet-}$ production (analyzed by DHE) [10]. This $\mathrm{H}_{2} \mathrm{O}_{2}$ production was found to be dependent on $\mathrm{B}[\mathrm{a}] \mathrm{P}$ metabolism via CYP1 activity (since inhibited by $\alpha-N F$; [10]); it occurred independently of any mitochondrial dysfunction, since no effect of either bongkrekic acid or oligomycin, two specific inhibitors of mitochondrial alterations which inhibited $\mathrm{B}[\mathrm{a}] \mathrm{P}$ induced apoptosis [10,16], was detected following $24 \mathrm{~h}$ of treatment with $\mathrm{B}[a] \mathrm{P}$ (unpublished data). In contrast, the $\mathrm{O}_{2}{ }^{\bullet-}$ production measured following a $48 \mathrm{~h}$-treatment was related to mitochondrial dysfunction since inhibited by both bongkrekic acid and oligomycin (unpublished data).

ROS production related to $\mathrm{B}[\mathrm{a}] \mathrm{P}$-metabolism via CYP1 activity was thus detected after $24 \mathrm{~h}$ of $\mathrm{B}[\mathrm{a}] \mathrm{P}$-treatment using the oxidation-sensitive fluorescent probe dihydrodichlorofluorescein diacetate (H2-DCFDA, $1 \mu \mathrm{M}$; Molecular Probes) [10]. After a $24 \mathrm{~h}$-co-incubation period with $\mathrm{B}[\mathrm{a}] \mathrm{P}$ and the fluoroprobe, cells were collected, washed twice with ice-cold PBS and analyzed using a FACSCalibur flow cytometer (Becton-Dickinson, Franklin Lakes, NJ), as previously described. The illustrated histograms are representative of three independent experiments.

Regarding mitochondria-dependent ROS production, this was detected after $48 \mathrm{~h}$ of $\mathrm{B}[\mathrm{a}] \mathrm{P}$-treatment using the oxidationsensitive fluorescent probe dihydroethidium (DHE, Molecular Probes). After $48 \mathrm{~h}$ of treatment, cells were collected and loaded with DHE $(5 \mu \mathrm{M})$ for $20 \mathrm{~min}$ at $37^{\circ} \mathrm{C}$. Cells were then washed twice with ice-cold PBS and analyzed using a FACSCalibur flow cytometer. The illustrated histograms are representative of three independent experiments.

\subsection{Analysis of lipid peroxidation}

Lipid peroxidation was measured using the fluoroprobe $\mathrm{C}_{11^{-}}$ BODIPY $^{581 / 591}$ (4,4-difluoro-5-[4-phenyl-1,3-butadienyl]-4-bora3a,4a-diaza-s-indacine-3-undecanoic acid; Molecular Probes), that incorporates into cell membranes, thereby allowing detection of lipid peroxidation. Following 48 or $72 \mathrm{~h}$-treatment of cells with $50 \mathrm{nM} \mathrm{B}[\mathrm{a}] \mathrm{P}$ and/or test compounds, medium was removed and cells were incubated for $2 \mathrm{~h}$ at $37^{\circ} \mathrm{C}$ with mediumdiluted probe (from $2 \mathrm{mM}$ stock in DMSO) at a final concentration of $10 \mu \mathrm{M}$. After washing in PBS, the oxidation of $\mathrm{C}_{11}$-BODIPY was measured by spectrofluorimetry (Spectramax Gemini, Molecular Devices), using two couples of wavelengths that allow measurement of the amount of oxidized $\left(\lambda_{\text {exc }}=485 \mathrm{~nm}-\right.$ $\left.\lambda_{\mathrm{em}}=535 \mathrm{~nm}\right)$ and non-oxidized probe $\left(\lambda_{\text {exc }}=590 \mathrm{~nm}-\right.$ $\lambda_{\mathrm{em}}=635 \mathrm{~nm}$ ). Lipid peroxidation was quantified by calculating the ratio of fluorescence between oxidized probe and total probe, which is independent of protein content [17].

\subsection{Measurement of $\mathrm{pH}_{\mathrm{i}}$}

The $\mathrm{pH}_{\mathrm{i}}$ of $\mathrm{F} 258$ cells cultured on glass coverslips was monitored using the $\mathrm{pH}$-sensitive fluorescent probe, carboxy-SNARF-1 (carboxy-seminaphtorhodafluor; Molecular Probes), as previously described [10]. Briefly, SNARF-loaded 
cells were placed in a continuously perfused recording chamber (at a temperature of $36 \pm 1^{\circ} \mathrm{C}$ ) mounted on the stage of an epifluorescent microscope (Nikon Diaphot). F258 cells were then excited with light at $514 \mathrm{~nm}$ and fluorescence from the trapped probe was measured at 590 and $640 \mathrm{~nm}$. The emission ratio 640/590 $\mathrm{nm}$ (corrected for background fluorescence) detected from intracellular SNARF was calculated and converted to a linear $\mathrm{pH}$ scale using in situ calibration obtained by the nigericin technique.

\subsection{Analysis of the iron uptake}

F258 cells were treated for 48 or $72 \mathrm{~h}$ with B[a]P (50 nM). During the last hours of treatment, F258 cells were also incubated for various times $(3-24 \mathrm{~h})$ with $10 \mathrm{mM}$ of $\left[{ }^{55} \mathrm{Fe}\right]$-iron chloride $\left({ }^{55} \mathrm{FeCl}_{3} 81.07 \mathrm{mC}_{\mathrm{i}} \mathrm{mg}^{-1}\right.$; Perkin-Elmer, Boston, MA). Following incubation, cells were washed three times with ice-cold PBS and lysed in $400 \mu \mathrm{L}$ of water. Labeled iron uptake was measured from $300 \mu \mathrm{L}$ of cell lysates mixed with $4 \mathrm{~mL}$ of Microscint ${ }^{\mathrm{TM}} 20$ scintillator (Packard) using a scintillation counter (Packard Instrument Co., Meriden, USA). The total iron uptake was calculated for each experiment from a linear scale determined using the same ${ }^{55} \mathrm{Fe}$ solution as the one used for cells. The amounts of proteins in cell lysates were then measured by the Bradford technique and quantities of normalized iron-uptake were deduced from radioactivity measurement corrected for by protein content.
The effect of test compounds on $\mathrm{B}[\mathrm{a}] \mathrm{P}(72 \mathrm{~h})$-induced iron uptake was analyzed using the same procedure as above but only with a $6 \mathrm{~h}$-incubation of cells with $10 \mathrm{mM}$ of $\left[{ }^{55} \mathrm{Fe}\right]$-iron chloride.

\subsection{Statistical analysis}

All data are quoted as mean \pm standard error of mean along with number of observations, $n$, corresponding to the number of separate cultures used. Analysis of variance followed by Newman-Keuls test was used to analyse the statistical significance of differences between treatments. Differences were considered significant at the level of $p<0.05$.

\section{Results}

\subsection{GM1 prevents $B[a] P$-induced apoptosis in $\mathrm{F} 258$ cells}

The first set of experiments was carried out in order to evaluate the effect of GM1 on the apoptosis induced by a $72 \mathrm{~h}$ treatment of F258 cells with $\mathrm{B}[\mathrm{a}] \mathrm{P}(50 \mathrm{nM})$. As shown in Fig. $1 \mathrm{~A}$, co-treatment with GM1 resulted in a dose-dependent reduction of apoptosis (as quantified by Hoechst 33342 staining of chromatin), with a maximum effect of about $30 \%$ at a concentration of $80 \mu \mathrm{M}$. Using propidium iodide (which stains only nucleus of necrotic cells), we verified that the protection
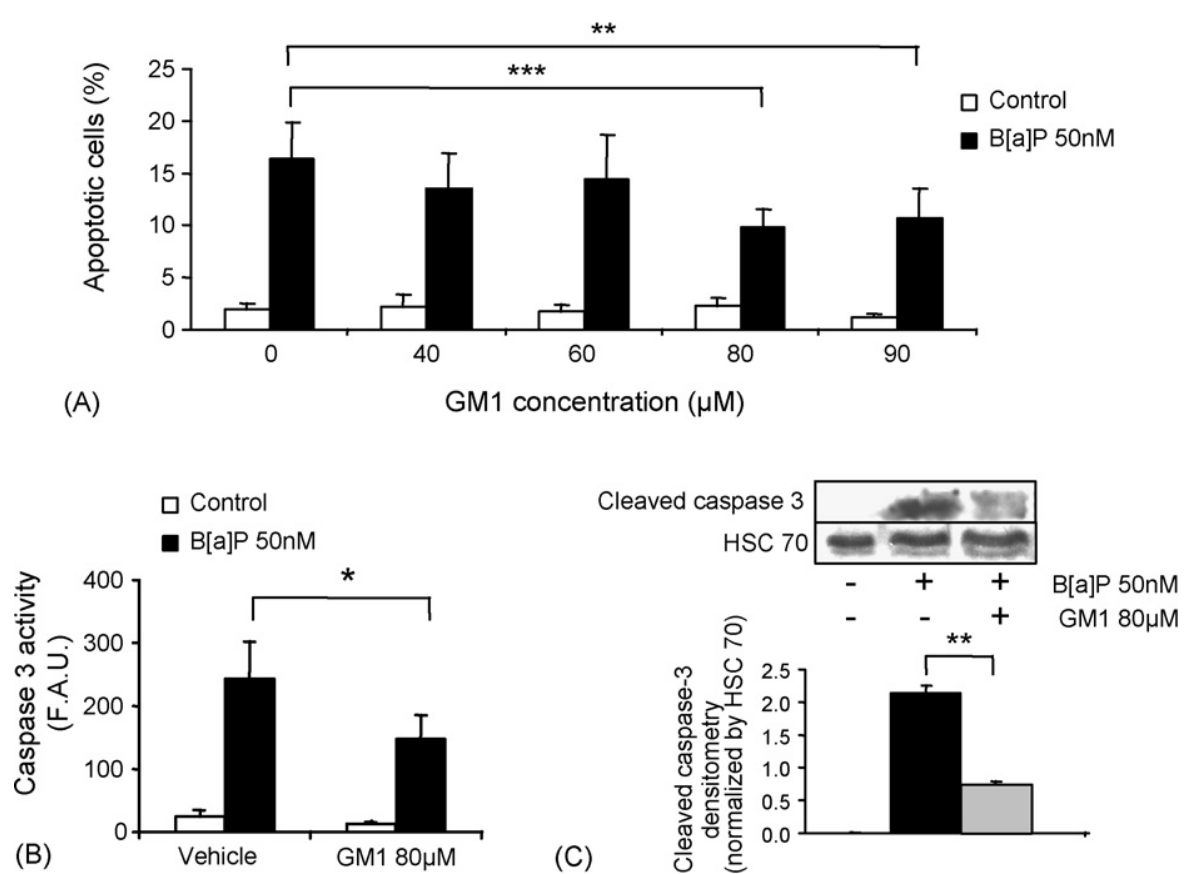

Fig. 1 - GM1 partly protected F258 cells from B[a]P-induced apoptosis. (A) F258 cells were treated or not (control) with B[a]P $(50 \mathrm{nM})$ in the presence or not of GM1 (0-90 $\mu \mathrm{M})$ for $72 \mathrm{~h}$. After collection and staining with Hoechst 33342, the percentage of apoptotic cells was obtained by fluorescence microscopy analysis of chromatin condensation and fragmentation. Results are given as mean \pm S.E.M. of six independent experiments. (B) Cells were treated or not (control) with $B[a] P$ in the presence or not (vehicle: DMSO) of $80 \mu \mathrm{M}$ of GM1. Caspase activity (as detected by cleavage of DEVD-AMC) was measured by spectrofluorimetry following a $72 \mathrm{~h}$-treatment. Data are given as mean S.E.M. of three independent experiments. ${ }^{*} p<0.05$, ${ }^{* *} p<0.01,{ }^{* * *} p<0.001 \mathrm{~B}[\mathrm{a}] \mathrm{P}$ vs. GM1 + B[a]P. (C) Cleavage of procaspase 3 was analysed by western blotting from cells treated $(+)$ or not $(-)$ with $B[a] P$ and/or GM1 for $72 \mathrm{~h}$. Blot representative of three independent experiments. Detection of HSC70 was used as loading control. 

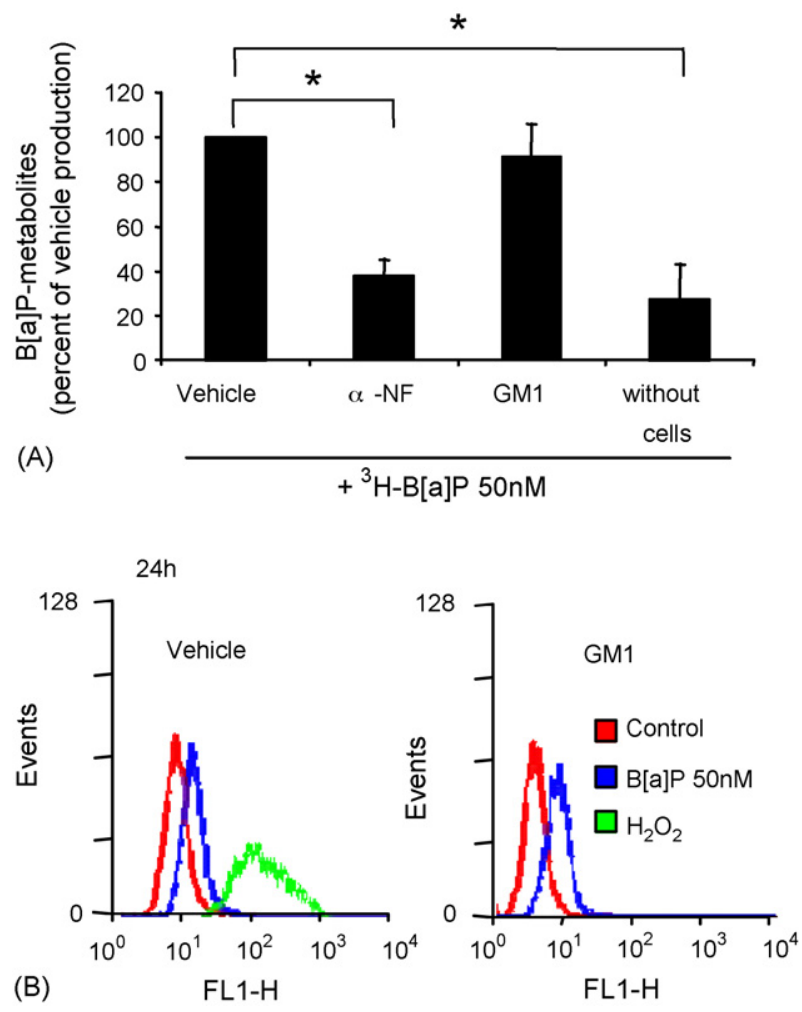

Fig. 2 - No effect of GM1 on the production of soluble metabolites and on the metabolism-related $\mathrm{H}_{2} \mathrm{O}_{2}$ production in B[a]P-treated F258 cells. (A) After a $24 \mathrm{~h}$ treatment with TCDD, F258 cells were treated for $4 \mathrm{~h}$ with $50 \mathrm{nM}^{3} \mathrm{H}-\mathrm{B}[\mathrm{a}] \mathrm{P}$ in the presence or not (vehicle: DMSO) of either $80 \mu \mathrm{M}$ GM1 or $10 \mu \mathrm{M} \alpha-\mathrm{NF}$. The production of hydrosoluble $\mathrm{B}[\mathrm{a}] \mathrm{P}$ metabolites was then analyzed with a scintillation counter. A sample free of cells was used as negative control. Results are given as \% of metabolic production measured from vehicle B[a]P-treated cells $(n=3$ independent experiments). ${ }^{*} p<0.05: \mathrm{B}[a] \mathrm{P}$ us. inhibitor $+B[a] P$. (B) Cells were treated or not (control) for $24 \mathrm{~h}$ with $\mathrm{B}[\mathrm{a}] \mathrm{P} 50 \mathrm{nM}$ in the presence or not (vehicle: DMSO) of GM1 $(80 \mu \mathrm{M}) \cdot \mathrm{H}_{2} \mathrm{O}_{2}$ production was analyzed using $\mathrm{H}_{2}$ DCFDA and flow cytometry. A 20 min-treatment with $\mathrm{H}_{2} \mathrm{O}_{2}$ was used as positive control for ROS production. Peaks are representative of three independent experiments.

afforded by GM1 $(80 \mu \mathrm{M})$ was not linked to a shift of cell death from apoptosis to necrosis (data not shown). Such a protective effect was confirmed when looking at the caspase 3 activation; indeed, a significant inhibition of the $\mathrm{B}[\mathrm{a}] \mathrm{P}$-elicited increase in caspase 3 activity (as determined by DEVD-AMC cleavage measurements) was evidenced in cells co-treated with GM1 (Fig. 1B). Moreover, this decrease in activity occurred along with a clear reduction of caspase 3 cleavage (as determined by Western Blot analysis; Fig. 1C).

3.2. Effects of GM1 on the apoptotic cascade induced by $\mathrm{B}[\mathrm{a}] \mathrm{P}$ in F258 cells

Before looking at the possible events in the $\mathrm{B}[\mathrm{a}] \mathrm{P}$-induced apoptotic cascade sensitive to GM1, we first tested the effect of this ganglioside on $\mathrm{B}[\mathrm{a}] \mathrm{P}$-metabolism via CYP1 activity. To this aim, the production of $\mathrm{B}[\mathrm{a}] \mathrm{P}$ metabolites and of metabolically related $\mathrm{H}_{2} \mathrm{O}_{2}$ was estimated in the presence of GM1 $(80 \mu \mathrm{M})$. In Fig. $2 \mathrm{~A}$, the production of soluble $\mathrm{B}[\mathrm{a}] \mathrm{P}$ metabolites was estimated using ${ }^{3} \mathrm{H}-\mathrm{B}[\mathrm{a}] \mathrm{P}$. Whereas, as expected, the wellknown CYP1 inhibitor $\alpha$-naphthoflavone $(10 \mu \mathrm{M})$ prevented metabolite production, no such a prevention was observed in the presence of GM1. Similarly, the related $\mathrm{H}_{2} \mathrm{O}_{2}$ production detected following a 24 h-treatment with $50 \mathrm{nM} \mathrm{B}[\mathrm{a}] \mathrm{P}$ remained unaffected, as evidenced by the rightward shift of DCF-fluorescent peak in co-treated cells (Fig. 2B). Altogether, these results rule out any effect of GM1 on CYP1-dependent metabolism of $\mathrm{B}[\mathrm{a}] \mathrm{P}$.

The next set of experiments was performed in order to seek a possible action of GM1 on different known events of the $\mathrm{B}[\mathrm{a}] \mathrm{P}$-elicited apoptotic cascade. As we have previously shown that two parallel pathways were involved in this cascade, that is, on one hand the p53 pathway and on the other hand the NHE1 pathway $[10,18]$, we decided to test first the effects of GM1 on the p53 activation and translocation. Based upon the fact that Serine 15-phosphorylation of this protein appears to be particularly important for its function, activation and nuclear translocation of this tumor suppressor protein were studied using staining of the Ser ${ }^{15}$ phosphorylated form of p53 by a specific antibody and analysis of the subcellular localization of this form by immunocytochemistry. The data illustrated in Fig. 3 clearly show that $\mathrm{B}[\mathrm{a}] \mathrm{P}$-induced $\mathrm{p} 53$ activation and translocation remained unaffected by the presence of $80 \mu \mathrm{M}$ GM1. Regarding the NHE1 pathway, the effects of GM1 $(80 \mu \mathrm{M})$ were tested on the intracellular alkalinization which has been previously related to NHE1 activation upon $\mathrm{B}[\mathrm{a}] \mathrm{P}$ treatment of F258 cells [10]. As shown in Fig. 4A, the alkaline

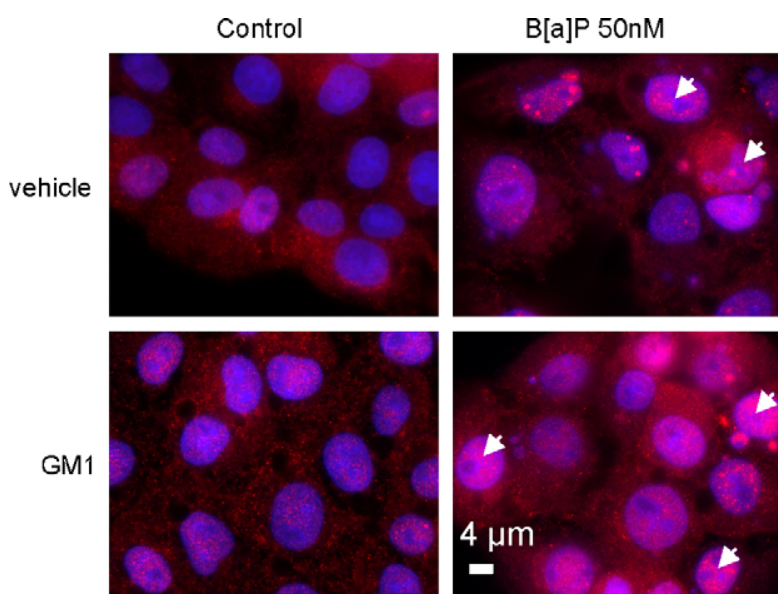

Fig. 3 - GM1 did not affect p53 activation in B[a]P-treated F258 cells. p53 phosphorylation on serine 15 and translocation to the nucleus were analyzed by immunofluorescence. F258 cells were seeded on glass coverlips, treated with $\mathrm{B}[\mathrm{a}] \mathrm{P} 50 \mathrm{nM} \pm \mathrm{GM} 180 \mu \mathrm{M}$ for $48 \mathrm{~h}$ and immunostained with specific phospho-p53 antibody. Control: B[a]P-untreated cells; vehicle: DMSO-treated, GM1-untreated cells. Arrow heads indicate the presence of p-p53 in cell nuclei. 

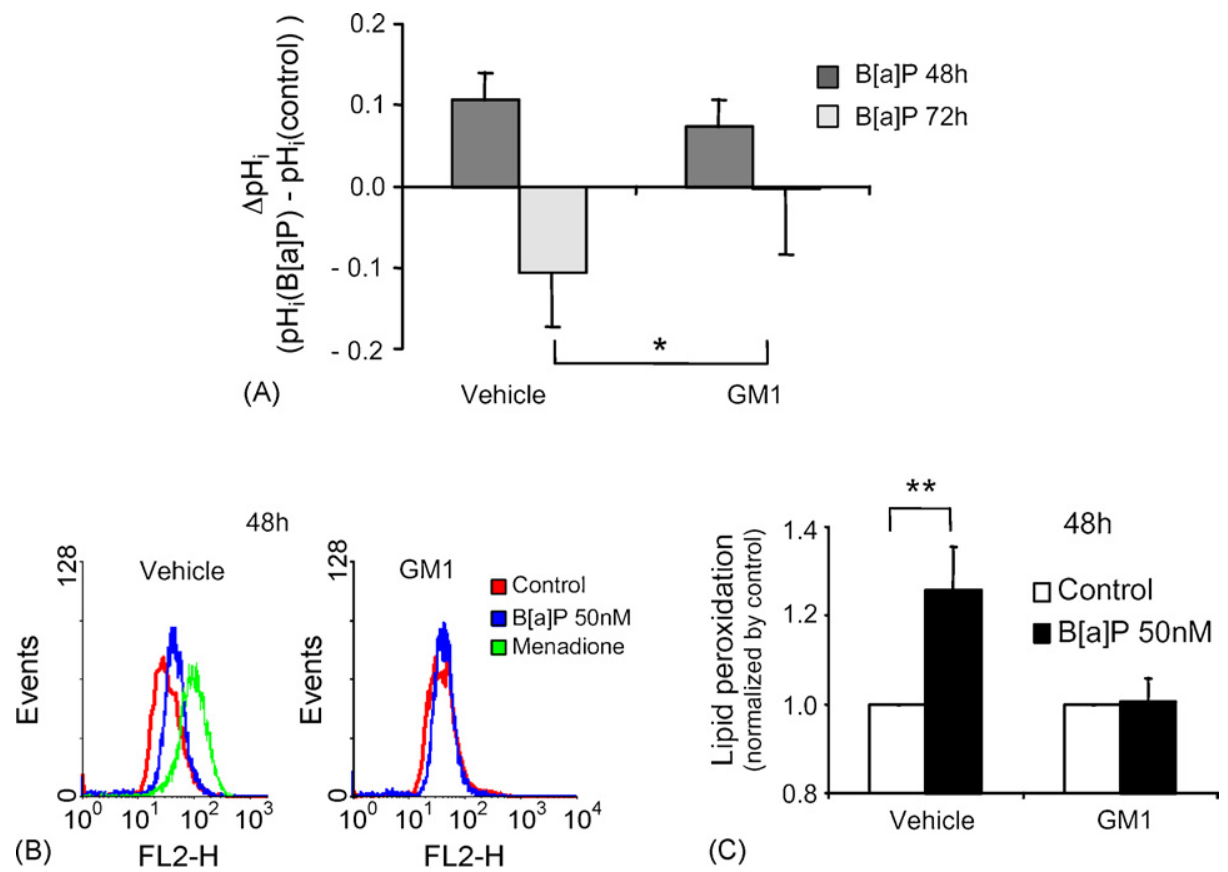

Fig. 4 - GM1 inhibited mitochondrial dysfunction. (A) Effects of GM1 (80 $\mu \mathrm{M})$ on the $\mathrm{pH}_{\mathrm{i}}$ variations induced by $\mathrm{B}[\mathrm{a}] \mathrm{P}(50 \mathrm{nM})$ in F258 cells following 48 or $72 \mathrm{~h}$ of treatment. $\mathrm{pH}_{\mathrm{i}}$ measurements were performed using the $\mathrm{pH}$-sensitive fluorescent probe, carboxy-SNARF-1. The graph represents the mean \pm S.E.M. of $\Delta \mathrm{pH}_{\mathrm{i}}\left(\mathrm{pH}_{\mathrm{i}\{\mathrm{B}[a] \mathrm{P}\}}-\mathrm{pH}_{\mathrm{i}\{\text { control\}}\}}\right)$ of eight experiments. (B) Effects of GM1 $(80 \mu \mathrm{M})$ on the $\mathrm{O}_{2}{ }^{--}$production recorded from F258 cells treated with $\mathrm{B}[\mathrm{a}] \mathrm{P}$ for $48 \mathrm{~h} . \mathrm{O}_{2}{ }^{--}$production was analyzed using DHE probe and flow cytometry. A 20 min treatment with menadione was used as positive control. The illustrated peaks are representative of three independent experiments. (C) Effects of GM1 (80 $\mu \mathrm{M})$ on the lipid peroxidation recorded using the $C_{11}$-BODIPY ${ }^{581 / 591}$ - probe from F258 cells treated with $B[a] P$ for $48 \mathrm{~h}(n=3$ independent experiments, results are expressed relatively to corresponding control, $\mathrm{B}[\mathrm{a}] \mathrm{P}$-untreated cells, i.e. with vehicle or inhibitor alone, for each condition). ${ }^{*} p<0.05,{ }^{* *} p<0.01$ : Control vs. B[a]P or B[a]P vs. inhibitor + B[a]P. In all panels, vehicle corresponds to DMSO-treated, GM1untreated cells.

$\mathrm{pH}_{\mathrm{i}}$ variation induced by a $48 \mathrm{~h}$-treatment with $50 \mathrm{nM}$ of $\mathrm{B}[\mathrm{a}] \mathrm{P}$ was not significantly affected by the presence of GM1. Altogether, these results show that neither p53 nor NHE1 activation by $\mathrm{B}[\mathrm{a}] \mathrm{P}$ were modified by GM1.

Our previous work has demonstrated that following activation of these two pathways, $\mathrm{B}[\mathrm{a}] \mathrm{P}$ elicited mitochondrion dysfunction leading to the development of a secondary intracellular acidification and a late ROS production $[10,18]$. In this context, we decided to look for possible effects of GM1 $(80 \mu \mathrm{M})$ on these two mitochondria-related events. As shown in Fig. $4 \mathrm{~A}$, the acid $\mathrm{pH}_{\mathrm{i}}$ variation induced by a $72 \mathrm{~h}$-treatment with $\mathrm{B}[\mathrm{a}] \mathrm{P}(50 \mathrm{nM})$ was fully prevented by GM1. Regarding mitochondrial ROS production, this has been previously reported to be responsible for lipid peroxidation elicited by $\mathrm{B}[\mathrm{a}] \mathrm{P}$-treatment [19]. In this context, the effects of GM1 were next evaluated on both mitochondrial ROS production (estimated by the rightward shift of DHE-related fluorescent peak as detected by flow cytometry) and lipid peroxidation following a $48 \mathrm{~h}$-treatment with $\mathrm{B}[\mathrm{a}] \mathrm{P}(50 \mathrm{nM})$. As shown in Fig. 4B and C, GM1 prevented these two phenomena. Altogether, these results point to mitochondrion as a target for GM1 protective action towards B[a]P-induced apoptosis since acidification and oxidative stress were inhibited in the presence of GM1.
3.3. Iron is involved in the apoptotic process elicited by $\mathrm{B}[\mathrm{a}] \mathrm{P}$ in $\mathrm{F} 258$ cells

Based upon our recent observation showing a protective effect of GM1 on ethanol-induced oxidative stress and lipid peroxidation via an effect on low molecular weight iron pool in rat hepatocytes [6], and having demonstrated that GM1 was capable of inhibiting $\mathrm{B}[\mathrm{a}] \mathrm{P}$-induced oxidative stress in F258 cells, we then decided to focus on the possible involvement of iron in the toxic effects of $\mathrm{B}[\mathrm{a}] \mathrm{P}$, with the aim of testing $\mathrm{GM} 1$ on these alterations, if any. We first demonstrated the involvement of iron in $\mathrm{B}[\mathrm{a}] \mathrm{P}$-induced apoptosis by means of two commonly used iron chelators, desferrioxamine (which is not capable of entering cells by passive diffusion and is hence mostly located within the late endosomes and lysosomes after endocytosis; [20]) and deferiprone. Indeed, co-treatment of F258 cells with $50 \mathrm{nM} \mathrm{B}[\mathrm{a}] \mathrm{P}$ and either $4 \mu \mathrm{M}$ desferrioxamine or $60 \mu \mathrm{M}$ deferiprone for $72 \mathrm{~h}$ resulted in a significant inhibition of the related apoptosis, as evidenced by the reduced percentage of cells exhibiting nuclear fragmentation (as estimated by Hoechst 33342 staining; Fig. 5A and B). In order to confirm such a protective effect of iron chelators, we next investigated their effects on $\mathrm{B}[\mathrm{a}] \mathrm{P}$-related lipid peroxidation following a 48 or $72 \mathrm{~h}$-treatment (Fig. $5 \mathrm{C}$ and D, respectively). 

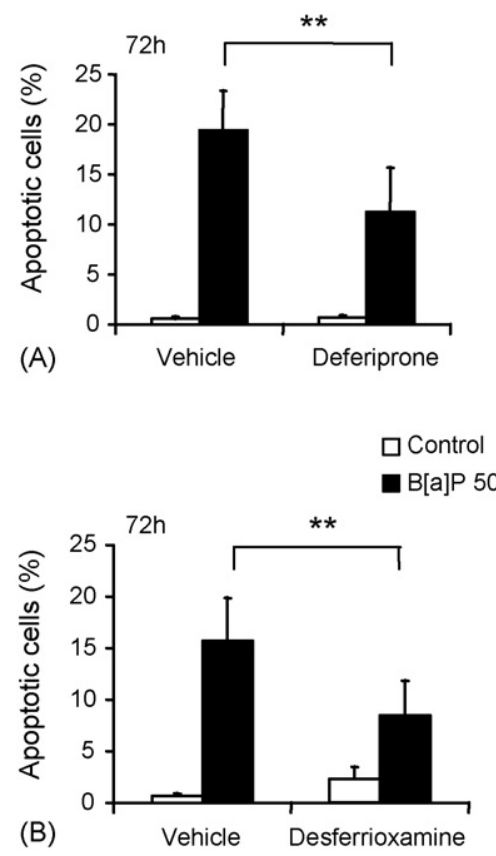
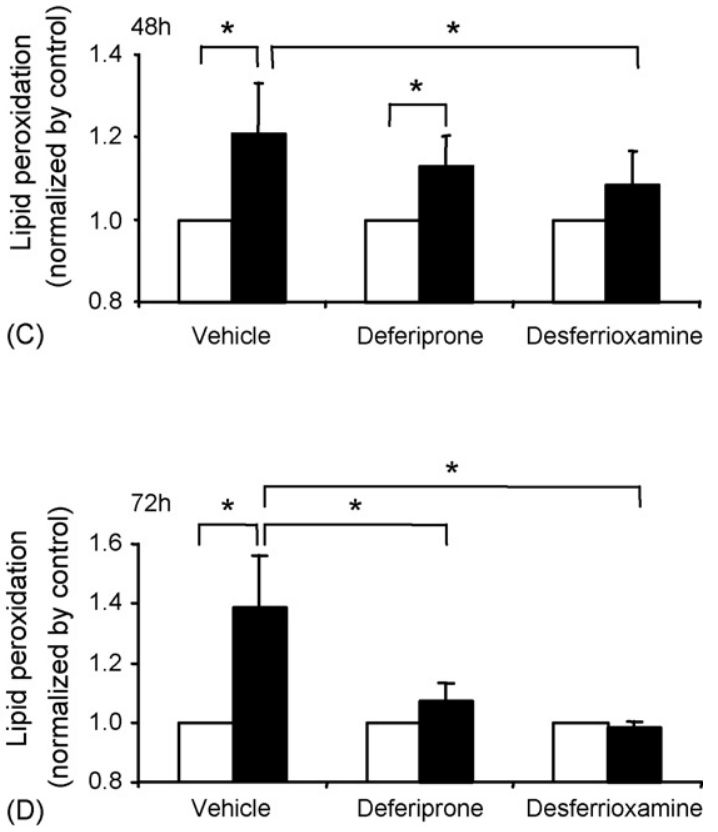

Fig. 5 - Iron was involved in B[a]P-induced apoptosis in F258 cells. Effects of two iron chelators, deferiprone $60 \mu \mathrm{M}$ (A) and desferrioxamine $4 \mu \mathrm{M}$ (B) on B[a]P (50 nM, $72 \mathrm{~h}$ )-induced apoptosis in F258 cells. Cells with apoptotic morphology were analyzed by fluorescence microscopy after Hoechst 33342 staining. The data are given as means \pm S.E.M. of three (A) or five (B) independent experiments. (C and D) Iron chelators inhibited B[a]P-induced lipid peroxidation following $48 \mathrm{~h}(\mathrm{C})$ or $72 \mathrm{~h}$ (D) of treatment. Lipid peroxidation was measured using the $\mathrm{C}_{11}-\mathrm{BODIPY}{ }^{581 / 591}$ probe and the results were expressed relatively to corresponding control, $\mathrm{B}[a] \mathrm{P}$-untreated cells, i.e. with vehicle or inhibitor alone, for each condition ( $n=4$ independent experiments). ${ }^{*} p<0.05,{ }^{* *} p<0.01$ : control vs. $\mathrm{B}[a] \mathrm{P}$ or $\mathrm{B}[a] \mathrm{P}$ us. inhibitor $+\mathrm{B}[a] \mathrm{P}$. In all panels, vehicle corresponds to DMSO-treated, iron chelator-untreated cells, and control to B[a]P-untreated cells.

Following $72 \mathrm{~h}$ of co-treatment, lipid peroxidation was fully inhibited whatever the chelator used, whereas after $48 \mathrm{~h}$, desferrioxamine was found to be more potent than deferiprone. Altogether, these results strongly support a role for low molecular weight iron in the toxic effects of $\mathrm{B}[\mathrm{a}] \mathrm{P}$ observed in F258 cells.

\subsection{GM1 inhibits the $\mathrm{B}[a] \mathrm{P}$-induced increase of iron uptake in F258 cells}

Since iron has been largely described as being involved in ROS production and lipid peroxidation (for review, see [21]) and in order to get further insight into the interactions of $\mathrm{B}[\mathrm{a}] \mathrm{P}$ with iron metabolism, we decided to quantify the iron uptake in F258 cells following various treatment times with $B[a] P$. The uptake of ${ }^{55} \mathrm{Fe}$ was estimated in these cells over an incubation period of 3-24 h using labeled iron; in other words, ${ }^{55} \mathrm{Fe}$ was added to cell culture media during the last 3, 6, 12 or $24 \mathrm{~h}$ of treatment until collection of cells. As illustrated in Fig. 6A, a significant increase in iron uptake was detected in F258 cells treated with $50 \mathrm{nM} \mathrm{B}[a] \mathrm{P}$ following a $48 \mathrm{~h}$-treatment. Such an effect was amplified when cells were further treated with $\mathrm{B}[\mathrm{a}] \mathrm{P}$, since the differences between control and treated cells were already significant following a $3 \mathrm{~h}$-incubation with ${ }^{55} \mathrm{Fe}$ (Fig. 6B). Besides, we found that these effects of $\mathrm{B}[a] \mathrm{P}$ on ${ }^{55} \mathrm{Fe}$ uptake were dose-dependent (data not shown). Fig. 6C clearly shows that this increase in iron uptake upon $\mathrm{B}[\mathrm{a}] \mathrm{P}$ exposure was related to both $\mathrm{B}[\mathrm{a}] \mathrm{P}$ metabolism by CYP1 and cytoskeleton since both $\alpha$-naphthoflavone $(10 \mu \mathrm{M})$ and cytochalasin B $(100 \mu \mathrm{M})$, an inhibitor of actin polymerization, prevented the $\mathrm{B}[\mathrm{a}] \mathrm{P}$-induced increase of ${ }^{55} \mathrm{Fe}$ uptake in F258 cells. Note that cytochalasin B was found to inhibit B $[a] \mathrm{P}$-induced apoptosis by about $30 \%$, as estimated by Hoechst staining of chromatin (data not shown).

Finally, in order to test whether GM1 was protecting F258 cells from $\mathrm{B}[\mathrm{a}] \mathrm{P}$-induced apoptosis by reducing the related enhancement of iron uptake, ${ }^{55} \mathrm{Fe}$ uptake was measured in cells co-treated with $\mathrm{B}[\mathrm{a}] \mathrm{P}$ and $\mathrm{GM} 1\left({ }^{55} \mathrm{Fe}\right.$ present in culture media within the last $6 \mathrm{~h}$ of treatment). As shown in Fig. 6C, the increase in iron uptake elicited by $\mathrm{B}[\mathrm{a}] \mathrm{P}$ exposure was markedly inhibited under such conditions, since no significant difference in the iron incorporation was found between GM1treated and B[a]P plus GM1-treated cells.

\section{Discussion}

In order to gain insight into the protective action of GM1 against chemically induced apoptosis, we tested its effect on different events of the cell death cascade elicited by $\mathrm{B}[\mathrm{a}] \mathrm{P}$ in F258 cells [10]. Since the protection by GM1 was partial, one could have supposed either a partial inhibition of $\mathrm{B}[\mathrm{a}] \mathrm{P}$ metabolism through CYP1 (as already evidenced for various compounds [22]), or a blockage of the permissive pathway 


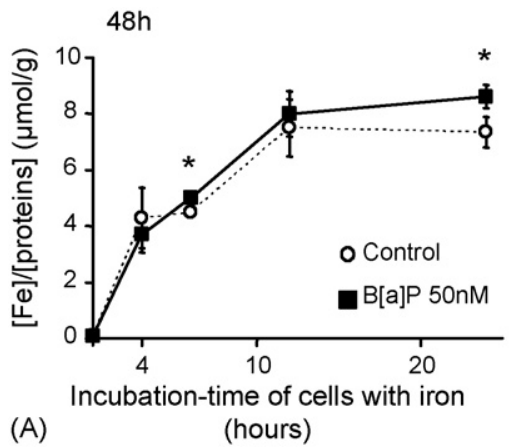

(A)

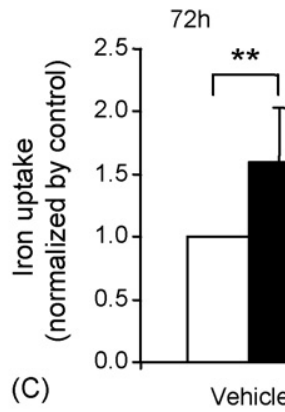

(C)

Vehicle

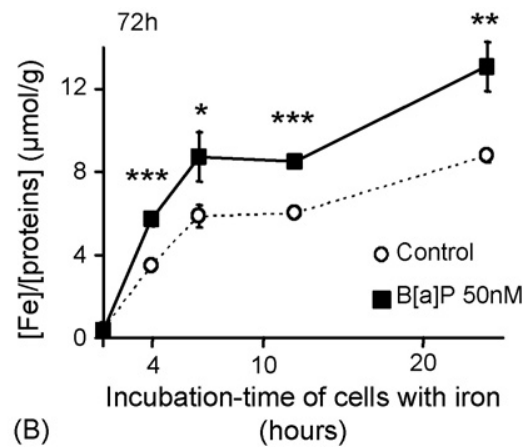

$\square$ Control

B[a]P 50nM

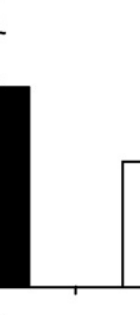

$\alpha \mathrm{NF}$

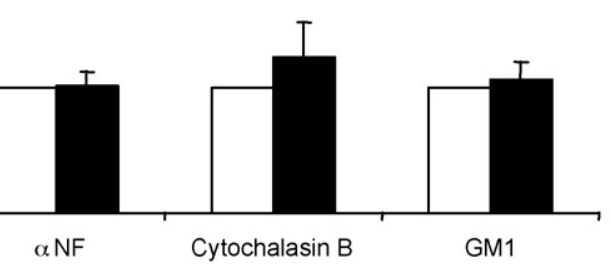

Fig. 6 - GM1 inhibited B[a]P-induced iron uptake in F258 cells. (A and B) Iron uptake was increased in B[a]P-treated cells. F258 cells were treated for $48 \mathrm{~h}$ (A) or $72 \mathrm{~h} \mathrm{(B)}$ with $50 \mathrm{nM} \mathrm{B}[a] P$. At different times before the end of treatment $(3,6,12$ or $24 \mathrm{~h})$, cells were also exposed to ${ }^{55} \mathrm{Fe} .{ }^{55} \mathrm{Fe}$ uptake was analyzed by scintillation counting and normalized by total protein content. The data are given as means \pm S.E.M. of three independent experiments. (C) Effects of GM1 $(80 \mu \mathrm{M})$ on ${ }^{55} \mathrm{Fe}$ uptake detected from $B[a] P(50,72 h)$-treated cells. The effects of $\alpha-\mathrm{NF}(10 \mu \mathrm{M})$ and cytochalasin B $(100 \mu \mathrm{M})$ were also tested. A $6 \mathrm{~h}$ before the end of treatment, cells were co-exposed to ${ }^{55} \mathrm{Fe} .{ }^{55} \mathrm{Fe}$ uptake was analyzed by scintillation counting and normalized by total protein content. The results were expressed relatively to corresponding control, $\mathrm{B}[a] \mathrm{P}$-untreated cells, i.e. with vehicle or inhibitor alone, for each test compound ( $n=6$ independent experiments). $" p<0.05, " p<0.01, "{ }^{\prime \prime} p<0.001$ : control vs. $\mathrm{B}[a] \mathrm{P}$ or $\mathrm{B}[a] \mathrm{P}$ vs. inhibitor $+\mathrm{B}[a] \mathrm{P}$. In all panels, control corresponds to $\mathrm{B}[a] \mathrm{P}$-untreated cells.

related to NHE1 activation whose inhibition protects cells towards $\mathrm{B}[\mathrm{a}] \mathrm{P}$-elicited apoptosis to an extent similar to that found with GM1 [10]. Regarding the former hypothesis, however, different observations argue against it: (1) GM1 did not alter the level of water-soluble $\mathrm{B}[\mathrm{a}] \mathrm{P}$-metabolite production; (2) the $\mathrm{H}_{2} \mathrm{O}_{2}$ production related to $\mathrm{B}[\mathrm{a}] \mathrm{P}$ metabolism remained unaffected. Therefore, GM1 appears to protect F258 cells independently of an action on PAH metabolism. It is worth noting that the activation of p53 pathway, known to be triggered following DNA damage by reactive metabolites [23], was not affected by GM1. Regarding an effect on NHE1 activation, this is unlikely to occur since the related intracellular alkalinization was not prevented by this compound. It therefore seemed that GM1 was acting downstream NHE1 and p53 activation.

Different studies, including ours, have shown that a mitochondrial dysfunction is associated with $\mathrm{PAH}$-induced apoptosis $[10,18,24]$. In order to test the effects of GM1 on mitochondrion, we focused on intracellular acidification and ROS production, two phenomena related to mitochondria dysfunction in B[a]P-treated F258 cells $[10,18]$. Given that GM1 may interfere with the development of not only ROS production but also lipid peroxidation [6], we decided to evaluate the effects of GM1 on oxidative stress by both analysing ROS production and quantifying oxidative damage on lipids. Our data clearly show that GM1 prevented mitochondria-dependent $\mathrm{B}[\mathrm{a}] \mathrm{P}$ induced acidification, therefore suggesting an effect, direct or not, of this compound on mitochondria. It is worth noting that an in vivo treatment of rats with GM1 has been reported to prevent the mitochondrial damage elicited in vitro in hippocampal slices [25]. With respect to the mitochondria-related oxidative stress, we also found a protection by GM1. In total, although GM1 interferes with mitochondrion-related oxidative stress in F258 cells, similarly to other models $[6,26]$, the present data are the first to show that GM1 is protective against apoptosis also by interfering with mitochondrion-related acidification. Note that we have recently shown this acidification to be an important factor in the B[a]P-induced apoptosis in F258 cells [16].

The observation that exogenous GM1 interferes with mitochondria-dependent events puzzled us since GM1 is supposed to incorporate into plasma membrane and to undergo recycling through endosomal and lysosomal membranes [27]. One explanation might be that upon exposure to exogenous GM1, survival pathways would be activated, as previously observed $[4,28]$, thereby possibly controlling the expression of anti- or pro-apoptotic proteins. With regard to that point, it is worth noting that (1) we have found that $\mathrm{B}[\mathrm{a}] \mathrm{P}$ induced acidification is related to $\mathrm{F}_{0} \mathrm{~F}_{1}$-ATPase [16] and that (2) $\mathrm{Bcl}-2$ is capable of modulating this ATPase and hence the 
related cytosolic acidification during cardiac ischemia [29]. In this context, the effects of GM1 on survival signalling pathways as well as on Bcl-2 family proteins clearly need further investigation.

Our recent data demonstrating an inhibitory effect of GM1 on the increase in intracellular low molecular weight iron pool elicited by exposing hepatocytes to ethanol [6], encouraged us first to test the involvement of iron in $\mathrm{B}[a] \mathrm{P}$-induced apoptosis and second, should any involvement be detected, to look at the effects of GM1 on iron uptake. Indeed, besides its essential role in cell functions, this metal, known to be trafficked by the endosomal-lysosomal route (for review, see [30]), is also commonly recognized to be highly toxic when present in its free chelatable form within cells, notably by catalyzing the generation of highly toxic ROS through reduction of $\mathrm{H}_{2} \mathrm{O}_{2}$ to $\mathrm{OH}^{\bullet}$ via the iron-catalyzed Fenton/Haber-Weiss reactions [21]. In order to test the involvement of iron in cell processes, specific chelators are often used [31]. Here, we determined for the first time that $\mathrm{B}[\mathrm{a}] \mathrm{P}$-induced oxidative stress was linked to iron in our model, since both desferrioxamine and deferiprone markedly inhibited lipid peroxidation. Besides, as these compounds significantly reduced $\mathrm{B}[\mathrm{a}] \mathrm{P}$-induced apoptosis (at a higher level than that obtained when lipid peroxidation was prevented by Vitamin E: decrease by $46.1 \pm 15.8 \%$ [deferiprone] and $47.8 \pm 6.1 \%$ [desferrioxamine] versus 17.8 $\pm 9.5 \%$ [Vitamin $E$ ], $n=5$ ), iron might play a role independently of its role in lipid peroxidation process. The fact that desferrioxamine, which localizes almost exclusively within lysosomes following endocytic uptake [20], was protective under our conditions, has to be emphasized since this might further suggest the involvement of the lysosomal pool of free iron. However, how this pool would be released during $\mathrm{B}[\mathrm{a}] \mathrm{P}$ elicited apoptosis remains to be determined.

Focusing on iron implication, we then wanted to test whether $\mathrm{B}[\mathrm{a}] \mathrm{P}$ induces changes in iron content, especially by modulating its uptake. Our observations that iron uptake was enhanced by $\mathrm{B}[\mathrm{a}] \mathrm{P}$ treatment is consistent with the observed protective effect of iron chelators, whose action is to markedly reduce the intracellular free iron content. The $\mathrm{B}[\mathrm{a}] \mathrm{P}$-induced iron uptake was further shown to be dependent on $\mathrm{B}[\mathrm{a}] \mathrm{P}$ metabolism and on active endocytosis, since inhibited by the CYP1 inhibitor $\alpha-N F$ and by cytochalasin B, respectively. With respect to the protective effect of GM1, the present results show an inhibition of iron uptake by this compound, which might explain its inhibitory effect on $\mathrm{B}[a]$ P-elicited lipid peroxidation. It is worth emphasizing here that cytochalasin $\mathrm{B}$, besides fully blocking $\mathrm{B}[\mathrm{a}] \mathrm{P}$-induced ${ }^{55} \mathrm{Fe}$ uptake, also reduced the related apoptosis to the same extent as GM1, thus pointing to an effect of GM1 on endocytosis process. However how GM1 affects iron uptake has yet to be determined. Several works have shown that an increase in iron uptake can derive from an increase in transferrin receptor CD71 expression and/or turnover [30,32]. In this context, one might then suppose that GM1, as one of the natural membrane components, might incorporate into plasma membrane when exogenously applied, thereby modifying the lipid bilayer composition. Such an incorporation might lead to stabilization of membrane fluidity thus directly blocking endocytosis phenomenon, and hence interfering e.g. with transferrin turnover [33]. Note that stimulation of iron transport by calcium has been previously shown to depend on membrane fluidity [34]. Besides, different studies have shown that GM1 prevented both the toxic effects and the increase in fluidity elicited by various exogenous stimuli $[5,6,35]$. It is also worth emphasizing here that $\mathrm{B}[\mathrm{a}] \mathrm{P}$ per se has been reported to perturb the physical organization of phosphatidylcholine membranes [36]; this might thus support the idea of an increase in iron uptake elicited by $\mathrm{B}[\mathrm{a}] \mathrm{P}$-induced membrane fluidity changes which might be prevented by GM1. Another possibility might stem from the observation that exogenous GM1 activates several signaling cascades in different cell models [37], which might then alter either the expression of proteins involved in iron import, such as CD71 or divalent metal transporter (DMT1) [38], or endocytosis processes [39]. Finally, another important aspect to be considered is the possible effect of exogenous GM1 on lipid rafts of B[a]P-treated cells, since these microstructures are involved in endocytosis process (for review, see [40]). Regarding that point, suffice it to say that exogenous application of gangliosides have been shown to displace glycosyl phosphatidyl inositol (GPI)-proteins normally anchored in Triton X100 $\left(4^{\circ} \mathrm{C}\right)$-insoluble rafts towards soluble domains [41].

In conclusion, along with our previous data on hepatocytes showing that GM1 was protective towards ethanol-induced toxicity by preventing the related increase in low molecular weight iron, we now present evidence that exogenous GM1 treatment affords some protection towards apoptosis triggered by DNA-damage not only through interfering with iron transport alterations but also through targeting of the mitochondrion-dependent acidification previously shown to be related to apoptosis.

\section{Acknowledgements}

We wish to thank Lydie Sparfel and Marc Le Vée for technical advice on metabolism experiments, and Valérie Lecureur and David Gilot for fruitful discussion. We also want to thank the microscopy platform and Stéphanie Dutertre (UMR 6061, CNRS, Rennes) for helpful advice on immunolocalization capture and analysis. This work was supported by the Institut National de la Santé et de la Recherche Médicale (INSERM), the Ligue Nationale Contre le Cancer (the Morbihan, Côte d'Armor and Ille et Vilaine Committees), Rennes Métropole and the Région Bretagne.

\section{Appendix A. Supplementary data}

Supplementary data associated with this article can be found, in the online version, at 10.1016/j.bcp.2006.07.014.

\section{R E F E R E N C E S}

[1] Cavallini L, Venerando R, Miotto G, Alexandre A. Ganglioside GM1 protection from apoptosis of rat heart fibroblasts. Arch Biochem Biophys 1999;370(2):156-62. 
[2] Ryu BR, Choi DW, Hartley DM, Costa E, Jou I, Gwag BJ. Attenuation of cortical neuronal apoptosis by gangliosides. J Pharmacol Exp Ther 1999;290(2):811-6.

[3] Huang F, Vemuri MC, Schneider JS. Modulation of ATP levels alters the mode of hydrogen peroxide-induced cell death in primary cortical cultures: effects of putative neuroprotective agents. Brain Res 2004;997(1): 79-88.

[4] Ferrari G, Greene LA. Promotion of neuronal survival by GM1 ganglioside. Phenomenology and mechanism of action. Ann NY Acad Sci 1998;845:263-73.

[5] Galisteo M, Rissel M, Sergent O, Chevanne M, Cillard J, Guillouzo A, et al. Hepatotoxicity of tacrine: occurrence of membrane fluidity alterations without involvement of lipid peroxidation. J Pharmacol Exp Ther 2000;294(1):160-7.

[6] Sergent O, Pereira M, Belhomme C, Chevanne M, Huc L, Lagadic-Gossmann D. Role for membrane fluidity in ethanol-induced oxidative stress of primary rat hepatocytes. J Pharmacol Exp Ther 2005;313(1):104-11.

[7] Seren MS, Lazzaro A, Yang CL, Canella R, Bassan M, Zanoni $\mathrm{R}$, et al. Orally administered glycolipid derivative LIGA20 reduces infarct volume and behavioral impairment after focal cerebral ischemia. J Pharmacol Exp Ther 1994;268(1):460-5.

[8] Chinnock P, Roberts I. Gangliosides for acute spinal cord injury. Cochrane Database Syst Rev )2005;(2). CD004444.

[9] Nebert DW, Roe AL, Dieter MZ, Solis WA, Yang Y, Dalton TP. Role of the aromatic hydrocarbon receptor and [Ah] gene battery in the oxidative stress response, cell cycle control, and apoptosis. Biochem Pharmacol 2000;59(1):65-85.

[10] Huc L, Sparfel L, Rissel M, Dimanche-Boitrel MT, Guillouzo A, Fardel O, et al. Identification of $\mathrm{Na}^{+} / \mathrm{H}^{+}$exchange as a new target for toxic polycyclic aromatic hydrocarbons. FASEB J 2004;18(2):344-6.

[11] Solhaug A, Refsnes M, Lag M, Schwarze PE, Husoy T, Holme JA. Polycyclic aromatic hydrocarbons induce both apoptotic and anti-apoptotic signals in Hepa1c1c7 cells. Carcinogenesis 2004;25(5):809-19.

[12] Matikainen TM, Moriyama T, Morita Y, Perez GI, Korsmeyer SJ, Sherr DH, et al. Ligand activation of the aromatic hydrocarbon receptor transcription factor drives Baxdependent apoptosis in developing fetal ovarian germ cells. Endocrinology 2002;143(2):615-20.

[13] Lutz CT, Browne G, Petzold CR. Methylcholanthrene causes increased thymocyte apoptosis. Toxicology 1998;128(2):151-67.

[14] Gilot D, Loyer P, Corlu A, Glaise D, Lagadic-Gossmann D, Atfi A, et al. Liver protection from apoptosis requires both blockage of initiator caspase activities and inhibition of ASK1/JNK pathway via glutathione S-transferase regulation. J Biol Chem 2002;277(51):49220-9.

[15] Huberman E, Selkirk JK, Heidelberger C. Metabolism of polycyclic aromatic hydrocarbons in cell cultures. Cancer Res 1971;31(12):2161-7.

[16] Huc L, Rissel M, Solhaug A, Tekpli X, Gorria M, Torriglia A, et al. Multiple apoptotic pathways induced by p53dependent acidification in benzo[a]pyrene-exposed hepatic F258 cells. J Cell Physiol 2006;208:527-37.

[17] Pap EH, Drummen GP, Winter VJ, Kooij TW, Rijken P, Wirtz $\mathrm{KW}$, et al. Ratio-fluorescence microscopy of lipid oxidation in living cells using C11-BODIPY (581/591). FEBS Lett 1999;453(3):278-82.

[18] Huc L, Gilot D, Gardyn C, Rissel M, Dimanche-Boitrel MT, Guillouzo A, et al. Apoptotic mitochondrial dysfunction induced by benzo(a)pyrene in liver epithelial cells: role of p53 and pHi changes. Ann NY Acad Sci 2003;1010:167-70.

[19] Elbekai RH, Korashy HM, Wills K, Gharavi N, El-Kadi AO. Benzo[a]pyrene, 3-methylcholanthrene and betanaphthoflavone induce oxidative stress in hepatoma hepa 1c1c7 Cells by an AHR-dependent pathway. Free Radical Res 2004;38(11):1191-200.

[20] Lloyd JB, Cable H, Rice-Evans C. Evidence that desferrioxamine cannot enter cells by passive diffusion. Biochem Pharmacol 1991;41(9):1361-3.

[21] Kruszewski M. Labile iron pool: the main determinant of cellular response to oxidative stress. Mutat Res 2003;531(1-2):81-92.

[22] Solhaug A, Ovrebo S, Mollerup S, Lag M, Schwarze PE, Nesnow S, et al. Role of cell signaling in B[a]P-induced apoptosis: characterization of unspecific effects of cell signaling inhibitors and apoptotic effects of $\mathrm{B}[\mathrm{a}] \mathrm{P}$ metabolites. Chem Biol Interact 2005;151(2):101-19.

[23] Ramet M, Castren K, Jarvinen K, Pekkala K, TurpeenniemiHujanen T, Soini Y, et al. Vahakangas $\mathrm{K}$, p53 protein expression is correlated with benzo[a]pyrene-DNA adducts in carcinoma cell lines. Carcinogenesis 1995;16(9):2117-24.

[24] Hiura TS, Li N, Kaplan R, Horwitz M, Seagrave JC, Nel AE. The role of a mitochondrial pathway in the induction of apoptosis by chemicals extracted from diesel exhaust particles. J Immunol 2000;165(5):2703-11.

[25] Bianchi R, Janigro D, Milan F, Giudici G, Gorio A. In vivo treatment with GM1 prevents the rapid decay of ATPase activities and mitochondrial damage in hippocampal slices. Brain Res 1986;364(2):400-4.

[26] Tyurin VA, Tyurina Y, Avrova NF. Ganglioside-dependent factor, inhibiting lipid peroxidation in rat brain synaptosomes. Neurochem Int 1992;20(3):401-7.

[27] Mobius W, Herzog V, Sandhoff K, Schwarzmann G. Intracellular distribution of a biotin-labeled ganglioside, GM1, by immunoelectron microscopy after endocytosis in fibroblasts. J Histochem Cytochem 1999;47(8):1005-14.

[28] Choi JS, Kim JA, Joo CK. Activation of MAPK and CREB by GM1 induces survival of RGCs in the retina with axotomized nerve. Invest Ophthalmol Vis Sci 2003;44(4):1747-52.

[29] Imahashi K, Schneider MD, Steenbergen C, Murphy E. Transgenic expression of Bcl-2 modulates energy metabolism, prevents cytosolic acidification during ischemia, and reduces ischemia/reperfusion injury. Circ Res 2004;95(7):734-41.

[30] Richardson DR, Ponka P. The molecular mechanisms of the metabolism and transport of iron in normal and neoplastic cells. Biochim Biophys Acta 1997;1331(1):1-40.

[31] Persson HL, Yu Z, Tirosh O, Eaton JW, Brunk UT. Prevention of oxidant-induced cell death by lysosomotropic iron chelators. Free Radical Biol Med 2003;34(10):1295-305.

[32] Kotamraju S, Chitambar CR, Kalivendi SV, Joseph J, Kalyanaraman B. Transferrin receptor-dependent iron uptake is responsible for doxorubicin-mediated apoptosis in endothelial cells: role of oxidant-induced iron signaling in apoptosis. J Biol Chem 2002;277(19):17179-87.

[33] Sorokin LM, Morgan EH, Yeoh GC. Transferrin endocytosis and iron uptake in developing myogenic cells in culture: effects of microtubular and metabolic inhibitors, sulphydryl reagents and lysosomotrophic agents. J Cell Physiol 1988;137(3):483-9.

[34] Nilsen T. Effects of calcium on hepatocyte iron uptake from transferrin, iron-pyrophosphate and iron-ascorbate. Biochim Biophys Acta 1991;1095(1):39-45.

[35] Nishio M, Fukumoto S, Furukawa K, Ichimura A, Miyazaki $\mathrm{H}$, Kusunoki S, et al. Overexpressed GM1 suppresses nerve growth factor (NGF) signals by modulating the intracellular localization of NGF receptors and membrane fluidity in PC12 cells. J Biol Chem 2004;279(32):33368-7.

[36] Jimenez M, Aranda FJ, Teruel JA, Ortiz A. The chemical toxic benzo[a]pyrene perturbs the physical organization of phosphatidylcholine membranes. Environ Toxicol Chem 2002;21(4):787-93. 
[37] Van Brocklyn JR, Vandenheede JR, Fertel R, Yates AJ, Rampersaud AA. Ganglioside GM1 activates the mitogenactivated protein kinase Erk2 and p70 S6 kinase in U-1242 MG human glioma cells. J Neurochem 1997;69(1):116-25.

[38] Paradkar PN, Roth JA. Post-translational and transcriptional regulation of DMT1 during P19 embryonic carcinoma cell differentiation by retinoic acid. Biochem J 2006;394(Pt 1):173-83.

[39] Sorio C, Saggioro D, Chieco-Bianchi L, Berton G. The monosialoganglioside GM1 induces internalisation and degradation of the CD4 antigen in U937 cells: evidence for a novel mechanism of CD4 down-modulation in a p56lcknegative cell line, which is independent of protein kinase $C$ activation. Biochem Biophys Res Commun 1993;191(3):1105-10.

[40] Parton RG, Richards AA. Lipid rafts and caveolae as portals for endocytosis: new insights and common mechanisms. Traffic 2003;4(11):724-38.

[41] Simons M, Friedrichson T, Schulz JB, Pitto M, Masserini M, Kurzchalia TV. Exogenous administration of gangliosides displaces GPI-anchored proteins from lipid microdomains in living cells. Mol Biol Cell 1999;10(10):3187-96. 